\title{
Distortion after Case Hardening of Steels
}

Jiří Hájek, Antonin Kříž, Tomáš Jirka

University of West Bohemia, Univerzitní 22, 30614 Plzeň, Czech Republic, E-mail: hajek@kmm.zcu.cz, kriz@kmm.zcu.cz,jirka@kmm.zcu.cz

Dimensional changes, or distortion, play a very important role in carburizing. To keep carburizing process productive and profitable, it is crucial that the resulting distortion is minimized. The purpose of this experiment was to carry out low-pressure carburizing and measure dimensional changes, residual stresses, characterize the resulting microstructures, and determine hardness in the specimens. These are the most important clues to the quality of the carburized layer. Experimental materials were the most widely-used carburizing steels: $\mathrm{C15}, 16 \mathrm{MnCr5}$ and 15NiCr13. Residual stresses in the surface were determined by X-ray stress measurement.

Keywords: Distortion, Carburizing, Low pressure carburising (LPC)

\section{Acknowledgement}

The assistance of the PILSEN TOOLS s .r. o. company with the experiments carried out for this paper is gratefully acknowledged.

This work was undertaken as part of the SGS-2015-016 project "Analysis of Surfaces of Assemblies and Tools by Surface Integrity Method and Impacts on End-Use Properties".

\section{References}

[1] HERRING, D. H., GERALD D. (2004). Reducing distortion in heat-treated gears., 35 pages. http://www.gearsolutions.com/article/detail/5655/reducing-distortion-in-heat-treated-gears

[2] LINDE GAS. Furnace Atmospheres No. 1: Gas Carburizing and Carbonitriding [online]. [Accessed 2015-0512]. http://www.linde-gas.com/en/processes/heat_treatment/carburising_carbonitriding/index.html

[3] KŘÍŽ, A. Tribologická analýza Pin on Disk [online]. [Accessed 2015-05-19]. http://www.ateam.zcu.cz/TRIBOLOGICKA_ANALYZA_PIN-ON-DISC.pdf

[4] SAlabOVÁ, P. (2013). Podtlaková cementace. Tribotechnika: Časopis o tření, opotřebování a mazání., No. 3.https://www.scribd.com/embeds/144596602/content?start_page=1\&view_mode=book\&access_key=key24msy9xmeorm0d9f2j8\&show_recommendations=false

[5] KARABELCHTCHIKOVA, O. (2007). Fundamentals of Mass Transfer in Gas Carburizing. Worcester, USA, Doctoral thesis. WORCESTER POLYTECHNIC INSTITUTE

[6] NOVA, I., MACHUTA, J. (2016). Monitoring of the Diffusion Processes during Carburizing Automotive Steel Parts, Manufacturing Technology, Volume 16, pages 225-230

[7] WENQUAN, S., JIAN, S., ANRUI, H., PUJUN, H. N.(2015). Research on Distribution of Residual Stresses of Cold Rolled Sheet Distorted Area Based on ANSYS, Manufacturing Technology, Volume 15, pages 220-226

[8] HÁEK, J., KŘÍŽ, A., HRDLIČKA, V. (2015). The Heat Treatment of Aluminium Bronzes, Manufacturing Technology, Volume 15, pages 35-41

[9] NOVÁK, M. (2011). Surface quality of hardened steels after grinding, Manufacturing Technology, Volume 11, pages 55-59

[10] VASILKO, K. (2011). Identification of „,natural“ breaker cut during the machining of carbon steels, Manufacturing Technology, Volume 11, pages 77-84 